\title{
症例報告
}

\section{消化管通過障害に伴う曖気がすっきり出ない不快感に対して メトクロプラミドが著効した症例}

\author{
春日真由美 ${ }^{1)}$, 京坂 $\quad$ 紅 $^{2)}$, 黒澤 $\quad$ 永 $^{3)}$, 余宮きのみ ${ }^{2)}$
}

1) 埼玉県立がんセンター 緩和ケア科 (現 独立行政法人 国立病院機構 埼玉病院 緩和ケア科), 2) 埼玉県立がんセンター 緩和ケア科,

3）社会医療法人 壮幸会 行田総合病院 緩和ケア科

受付日 2014 年 7 月 26 日/改訂日 2014 年 11 月 4 日/受理日 2014 年 11 月 23 日

【症例 1】81歳，女性．噴門部胃がん，消化管内に空気が溜まってくると心窩部の重苦感が増強していたが，曖気にて症 状軽減を認めていた．曖気がすっきり出ない苦しさが続いていたため, メトクロプラミドの持続皮下注を開始したところ, 曖気が出やすくなり, 上腹部の膨満感は緩和された.【症例 2】 57 歳, 男性. 膵頭部がんにて消化管通過障害を認めていた. 腹部膨満感を伴った上腹部の不快感を訴えており, 曖気にて改善を認めていた。メトクロプラミドの持続皮下注を開始した ところ曖気がスムーズに出るようになり，上腹部の不快感が軽減した.【考察】がんによる消化管通過障害に伴った曖気が すっきり出ない苦痛症状に対して, メトクロプラミドの持続投与が有用な選択肢の 1 つであることが示唆された. 消化管通 過障害がある場合, メトクロプラミドによる蠕動方進作用により胃に溜まっていたガスが上昇逆流し, 曖気が促進されやす くなることが推測された.

Palliat Care Res 2015; 10(1): 524-8

Key words: 曖気，消化管通過障害，メトクロプラミド，緩和ケア，がん患者

\section{緒 言}

胃に溜まったガスが音を伴って食道・口腔を経て体外に排 出される現象を曖気，おくび，または俗に“げっぷ”という． 嚥下に伴って若干の空気が胃内に入り，胃底部に貯留したガ ス（胃泡）が一定量になると，噴門部が開いて口から出てく る．食べすぎや炭酸飲料の飲用後に生理的に出ることもある が, 病的な曖気は上部消化管の疾患に多く, 食道裂孔へルニ ア，胃・十二指腸潰瘍，幽門狭窄症，胃がんなどがある ${ }^{1)}$. がん患者では，がんの進行などに伴い消化管の通過障害を きたすことがある。それに伴い，停留した内容物が消化管を 伸展することで，迷走神経を介して嘔吐中枢が刺激され悪 心，嘔吐を引き起こす。また消化管内容量の増大に伴い，心 窩部の重苦感・膨満感，頻回の曖気が出現することもある.

曖気により消化管内に溜まったガスが胃から排出される と, 不快な症状は一時軽減するため, 腹圧をかけガスを出そ うとするが，スムーズに出てこないという苦痛を訴える場合 がある.

今回，がんによる消化管通過障害に伴いがスが消化管に貯 留しやすく，曖気がすっきり出ない苦痛が強かった患者に対 して, メトクロプラミドを持続投与したところ著効した症例 を経験したので報告する。

本稿では，個人が同定できないように内容の記述に倫理的 配慮を行った

\section{症例提示}

\section{1 症例 1}

【症 例】 81 歳, 女性.

【現病歴】 2012 年 2 月に食欲不振を主訴に近医を受診, 噴 門部胃がん Stage IV と診断された。胃噴門部の閉塞をきたし ており, 周囲リンパ節転移と後腹膜への直接浸潤もあったた め, 根治手術は不能であり, 食道下端で切離し食道空腸バイ パス術が施行された。術後に化学療法を開始したが，悪心が 増強し数日で中止となった。 2012 年 4 月, 症状緩和目的で埼 玉県立がんセンター（以下, 当センター）緩和ケア科初診と なり, その後食欲低下, 体動困難が進み, 2012 年 5 月入院と なった。

【入院後経過】入院時には経口摂取は著明に減少しており, がん終末期予後予測指標としての PPI（palliative prognostic index $)^{2)}$ は 6 点と予後週単位であることが予想され, 積極的な 精査は患者の希望のもと施行しなかった，消化管内にガスが 溜まってくると, 心窩部の重苦感やこみ上げが増強し,「げっ ぷが出そうだけど出なくて苦しくなる，出るとすっきりす る」「食後に胃がごろごろして張ってきて, 唾液が上がってく る. 空気や唾が出ると楽になる」と, 曖気にて症状軽減を認 めていた。こみ上げ，悪心に関しては消化管通過障害の可能 性を考え, 外来でベタメタゾン $2 \mathrm{mg}$ /日の内服投与を開始し ていたが，小腸までの薬剤の通過が妨げられ，経口摂取では 薬効が十分に得にくいことも考えられたため, 入院後べタメ

Corresponding Author: 春日真由美| 独立行政法人 国立病院機構 埼玉病院 緩和ケア科

₹ 351-0102 埼玉県和光市諏訪 2-1

TEL 048-462-1101 FAX 048-464-1138 Email: zn4ha2@bma.biglobe.ne.jp 


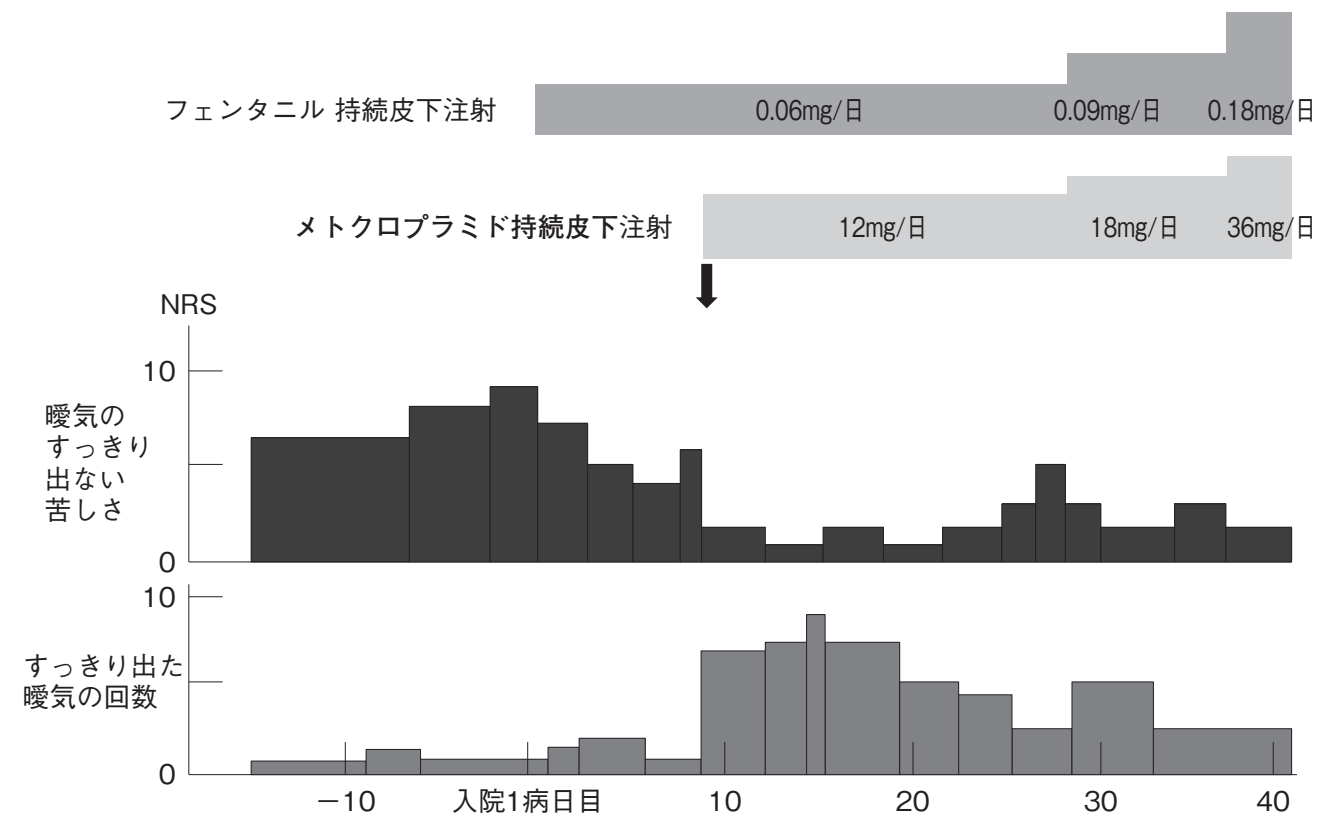

図 1 症例 1 の治療経過と症状の変化

タゾン $6 \mathrm{mg}$ /日へ増量し，内服から皮下注射へ変更した。疝 痛は認めておらず，排便や排ガスがあったため完全腸閉塞に は至っていないと判断した。 心窩部の重苦感に関しては, 消 化液，ガスの貯留に伴い胃が伸展していることや，胃がんに よる内臓痛が考えられたため, フェンタニルの持続皮下注射 を $2.5 \mu \mathrm{g}$ /時より開始した。 その後症状は若干の改善を認めた が，曖気のすっきり出ない苦しさはNRS（numerical rating scale): $5 / 11$ 程度と持続していたため, 第 9 病日目にメトクロ プラミドの持続皮下注射を $12 \mathrm{mg}$ /日より開始した。開始にあ たって，本人と家族に有害事象など含めて説明をし同意を得 た．メトクロプラミド開始翌日より曖気が出やすくなり，1 日の曖気の回数も増加し, 上腹部の膨満感は軽減した。 メト クロプラミド投与開始後 32 日目に多臓器不全を合併し死亡 退院となったが，投与期間中は嘔吐や疝痛などの消化器症状 の悪化や有害事象は認められず, 安全に投与できた（図 1).

\section{2 症例 2}

【症 例】57 歳, 男性

【現病歴】 2011 年 10 月より心窩部痛, 背部痛が出現し, 2011 年 12 月, 当センター消化器内科紹介受診. 膵頭部がん, 多発肝転移と診断された。手術は困難であり，化学療法を施 行された。 2012 年 5 月, 悪心が増強し, 経口摂取困難となっ たため入院となった.

【入院後経過】入院時の造影 $\mathrm{CT}$ 検査では膵頭部にかけての 腫瘍と十二指腸の壁肥厚を認めており，腸管への浸潤が疑わ れた(図 2)。ADL は著明に低下しており， $\mathrm{PPI}^{2}$ は 6 点であっ た，消化管内に空気が溜まってくると，上腹部の不快感が増 強し, 明らかに食事により悪心が増強し, 曖気や嘔吐により 症状軽減を認めていた。患者は「胃が戻ろうとして気持ち悪 くなる、げっぷが出れば落ち着く」「げっぷがすっきり出てこ ない，起き上がったり，動いた時にはげっぷが出てきて楽に

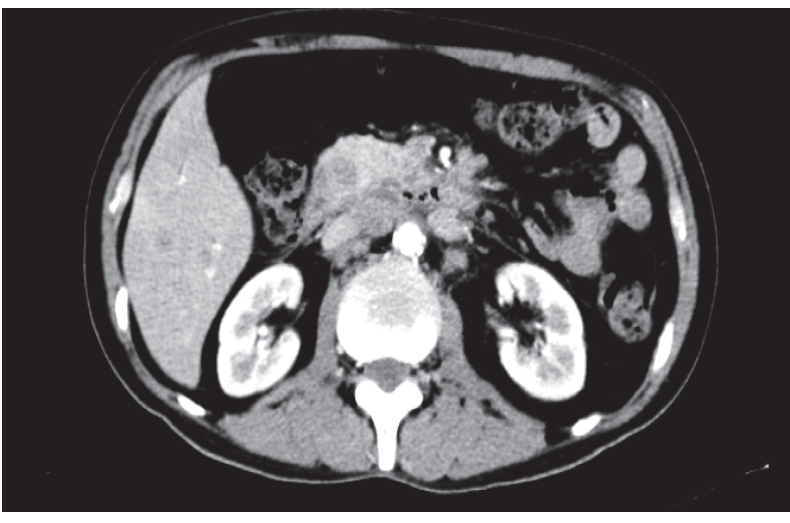

図 2 症例 2 の腹部造影 CT 検査 膵頭部付近に腫瘍を認める。

十二指腸下部の壁肥厚を認め, 十二指腸浸潤が疑われる.

なる」と, 曖気のすっきり出ない苦痛を強く訴えていた，心 窩部痛に関しては, 患者は「ガスが通過する痛み」と表現し ており, 膵臓がんによる内臓痛と, ガスが十二指腸の狭窄部 位を通過する際の蠕動痛と評価した。排便の停止や疝痛発作 などの消化管閉塞に伴う症状は認めなかった. 外来で開始し たフェンタニル貼付薬 $12.5 \mu \mathrm{g} /$ 時に併用して, 入院後よりオ キシコドン $10 \mathrm{mg} /$ 日の持続皮下注射を開始した。悪心に対し ては 1 日 2 回, 塩酸ヒドロキシジン $50 \mathrm{mg} /$ 日の点滴投与を開 始した。 その後痛みの軽減を認めたが, 悪心と, 曖気の出な い苦しさは続き, 緩和ケアチームに依頼があった。

食後の腹部膨満感を伴う覀心や曖気の出にくさに対し, 第 13 病日よりメトクロプラミド $16 \mathrm{mg} /$ 日の持続皮下注射を開 始したところ, 開始翌日よりスムーズに曖気が出るようにな り, 上腹部の不快感が軽減し, 経口攝取も可能となった。 すっきり出た曖気の回数も, 投与後は 1 日 8 回程度へ増加し 

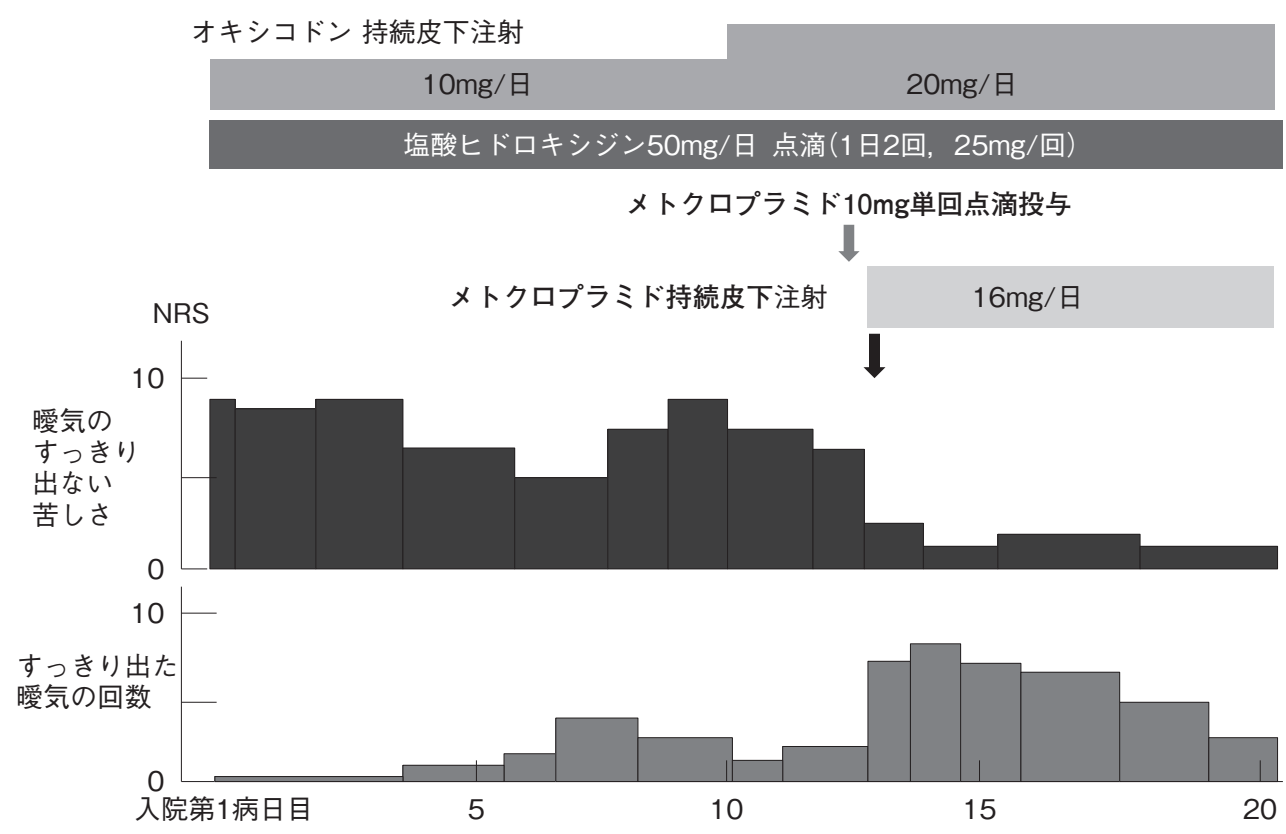

図 3 症例 2 の治療経過と症状の変化

た。肝不全が進行し第 21 病日に永眠されたが，投与期間中に 嘔吐や腹痛の増強は認めず，十分な症状緩和が得られた（図 3).

\section{考 察}

今回，がんによる消化管通過障害に伴いガスが消化管に貯 留しやすく, 曖気がすっきり出ない苦痛が強かった患者に対 してメトクロプラミドを持続投与したところ，曖気が促進さ れ, 症状緩和への患者の満足感が得られた。

曖気に関する報告としては，頻回な曖気による苦痛に対す る薬物治療の症例報告が散見される ${ }^{3 \sim 5)}$ 。しかし, 今回報告 したような“曖気が出そうだが出ない苦痛”に対しては，炭 酸飲料水についての報告はあるものの ${ }^{6,7)}$, 薬物治療について は，われわれが検索したかぎりでは認めなかった。

今回の “曖気が出そうだが出ない苦痛” 症状の機序として は，消化管内に貯留したガスが排出されないための苦痛と考 えられる，その原因としては，消化管の機械的あるいは機能 的な通過障害が考えられる。

担がん患者の中には，消化器がん自体の進行や，がん性腹 膜炎などがんの再発・転移により消化管通過障害に伴う身体 症状が出現する場合がある。また機械的な要因がなくても, 手術やオピオイドの使用に伴い, 腸管麻瘏などの消化管機能 障害が出現し, さまざまな消化器症状を招き，患者の全身状 態怙よび QOL を著しく低下させることも少なくない ${ }^{8,9)}$.

今回の症例では，上部消化管通過障害の有無に対する内視 鏡検査などの精査は患者が希望せず，また生命予後が週単位 であることが予想され2），侵襲的な精査は適応ではないと判 断しため検査は行わなかった。このように，進行がんにおけ る消化管通過障害の診断は，検査による確定診断が適切でな い場合が多い，そのため，患者の苦痛症状に焦点を当てて治
療的診断を行っていく必要がある.

症例 1 は，胃がんによる胃噴門部の完全閉塞により食道空 腸バイパス術が施行された。切除不能の消化器がんによる消 化管通過障害に対し, 症状緩和のための消化管バイパス術は QOL 改善に貢献し, 生存期間の延長にもつながることがあ $3^{10)}$. しかし消化管内容の排泄遅延が問題であり, 消化管バ イパス術を行っても必ずしも満足な経口摂取ができない点が 指摘されており ${ }^{11)}$, 術後の再閉塞の発生率は 10～50\%という 報告がある ${ }^{12)}$. 症例 1 に関しても, 吻合部の浮腫や再狭窄, 腹膜播種などが要因となり，通過障害をきたした可能性が考 えられた。

症例 2 では, 消化管造影検査や内視鏡検査は施行しなかっ たが, 造影 $\mathrm{CT}$ 検査では膵頭部の巨大な腫瘍を認めており, 消化管の機械的な通過障害の可能性が示唆された.

今回, 曖気が促進されたのは, メトクロプラミドによる蠕 動克進作用によると考えられる.

メトクロプラミドは, 消化管に存在するドパミン $\left(\mathrm{D}_{2}\right)$ 受 容体を遮断することにより，ドパミン神経による平滑筋収縮 の抑制を解除し, 消化管蠕動を促進する. そのため, 消化管 内容物を口側から肛門側へ移動させ, 胃部停滞を改善し, 胃 もたれ，悪心などの症状を軽減させる ${ }^{13,14)}$

胃内のガスは, 本来通過障害がない場合は腸へ排出され, そのほとんどが血液中に吸収され, 肺から呼吸に伴い排出さ れる ${ }^{15)}$. 消化管の通過障害はあっても完全閉塞ではない場 合, 胃内の液体などはメトクロプラミドによる蠕動促進に伴 い, 胃から腸へ少量ずつ排出されていくため嘔吐には至らな いが, 胃に溜まっていたガスは蠕動運動により上昇逆流し て, 曖気として口から排出されやすくなるということが推測 される。症例 1 では, 胃は食道下端で切離され, 食道空腸吻 合術が施行されている.メトクロプラミドの消化管運動賦活 作用には, 食道体部の収縮運動の増強作用が報告されてお 
$り^{16 \sim 18)}$, 食道の蠕動立進に伴い食道内のガスが曖気となり 排出促進されたと考えられた。

メトクロプラミドの使用用量として，1 例目は $12 \mathrm{mg} /$ 日よ り開始し，2 例目は $16 \mathrm{mg}$ /日より開始したが，持続投与量に 関しては 24 時間あたりの初期投与量は $0.5 \sim 2 \mathrm{mg} / \mathrm{kg}$ とされ ている.メトクロプラミドは投与量を増やすと効果が高くな

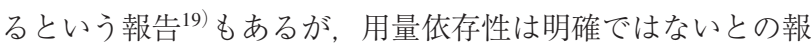
告 ${ }^{20)} も あ る 。$ 今回は低用量で効果を認めた。投与量について は, 今後の検討が必要である。

\section{結 論}

がんによる消化管通過障害に伴い，曖気がすっきり出ない 苦痛症状にメトクロプラミドの持続投与が著効した症例を報 告した。このような症状に対する薬物治療の報告は認められ ていないが, メトクロプラミドの持続投与が有用な選択肢の 1つであることが示唆された。今後さらに通過障害の程度に ついての評価もあわせ，症例を蓄積し，検討していくことが 必要である。

\section{文 献}

1）西野隆義. 胸やけ・げっぷ。臨と薬物治療 1993; 12: 8158

2) Morita $T$, Tsunoda $J$, Inoue $S$, et al. The palliative prognostic index: a scoring system for survival prediction of terminally ill cancer patients. Support Care Cancer 1999; 7: 128-33.

3）島田隆男，前田 温。逆流性食道炎および非びらん性逆 流症を対象としたラベプラゾール $\mathrm{Na}$ 錠 $10 \mathrm{mg}$ 「YD」の 臨床的有用性の検討. 医と薬学 2012; 67: 617-21.

4）山口恭広．難治性の曖気に姜桂湯が有効であった一例. 東方医 1993; 9: 66.

5）井上博喜, 岡 洋志, 八木清貴, 他. 難治性の曖気に吳 茱萌湯が奏効した一例。日東洋医誌 2007; 58: 861-5.

6) Pouderoux P, Frierman N, Shirazi P, et al. Effect of carbonated water on gastric emptying and intragastric meal distribution. Dig Dis Sci 1997; 42: 34-9.

7) Shmerling R. Squelching Your Belching. Quirky Body Series. Harvard Health Publications, 2010.

8) Stephenson J, Davies A. An assessment of aetiology-based guidelines for the management of nausea and vomiting in patients with advanced cancer. Support Care Cancer 2006; 14 : 348-53.

9) Bentley A, Boyd K. Use of clinical pictures in the management of nausea and vomiting: a prospective audit. Palliat Med 2001;
15: 247-53.

10) Blair SL, Chu DZ, Schwarz RE. Outcome of palliative operations for malignant bowel obstruction in patients with peritoneal carcinomatosis from nongynecological cancer. Ann Surg Oncol 2001; 8: 632-7.

11）松田正道, 渡邊五朗, 橋本雅司, 他. 十二指腸閉塞に伴 う膵癌に対する消化管バイパス術の有効性と適応につい て. 膵臓 2013; 28: 62-6.

12) Feuer DJ, Broadley KE, Shepherd JH, et al. Systematic review of surgery in malignant bowel obstruction in advanced gynecological and gastrointestinal cancer. The Systematic Review Steering Committee. Gynecol Oncol 1999; 75: 313-22.

13) Bruera ED, MacEachern TJ, Spachynski KA, et al. Comparison of the efficacy, safety, and pharmacokinetics of controlled release and immediate release metoclopramide for the management of chronic nausea in patients with advanced cancer. Cancer 1994; 74: 3204-11.

14）福原 武, 中山 沃, 福田博之, 他. $\mathrm{N}-$ - (diethylaminoethyl )-2-methoxy-4-amino-5-chlorobenzanide dihydrochlorideの胃および小腸運動におよぼす影響。 日平滑筋会誌 1966; 2: 15-21.

15) Sahakian AB, Jee SR, Pimentel M. Methane and the gastrointestinal tract. Dig Dis Sci 2010; 55: 2135-43.

16) Mercado U, Arroyo de Anda R, Avendaño L, et al. Metoclopramide response in patients with early diffuse systemic sclerosis. Effects on esophageal motility abnormalities. Clin Exp Rheumatol 2005; 23: 685-8.

17) DiPalma JA, Perucca PJ, Martin DF, et al. Metoclopramide effect on esophageal peristalsis in normal human volunteers. Am J Gastroenterol 1987; 82: 307-10.

18）眞部紀明，畠 二郎，春間 賢，消化管運動機能改善薬 の実力と使い方.レジデント 2014; 7: 32-9.

19) Wallenborn J, Gelbrich G, Bulst D, et al. Prevention of postoperative nausea and vomiting by metoclopramide combined with dexamethasone: randomized double blind multicentre trial. BMJ 2006; 333: 324.

20) Henzi I, Walder B, Tramèr MR. Metoclopramide in the prevention of postoperative nausea and vomiting: a quantitative systematic review of randomized, placebo-controlled studies. $\mathrm{Br} \mathrm{J}$ Anaesth 1999; 83: 761-71.

著者の申告すべき利益相反なし 


\title{
Case Report
}

\section{Patients in whom metoclopramide effectively relieved discomfort associated with gastrointestinal obstruction-related belching insufficiency}

\author{
Mayumi Kasuga $^{1)}$, Beni Kyosaka ${ }^{2)}$, Hisashi Kurosawa ${ }^{3)}$ and Kinomi Yomiya ${ }^{2)}$ \\ 1) Department of Palliative Care, Saitama Cancer Center (Currently Department of Internal Medicine, National Hospital Organization \\ Saitama National Hospital), 2) Department of Palliative Care, Saitama Cancer Center, \\ 3) Department of Palliative Care, Gyoda General Hospital
}

Case 1: A female, aged 81 years, with cardiac stomach cancer. Air retention in the digestive tract aggravated discomfort of the epigastric region, but belching relieved the symptom. As belching insufficiency persisted, the continuous subcutaneous injection of metoclopramide was started. Belching was promoted, and swelling of the upper abdomen was relieved. Case 2: A male aged 57 years. Gastrointestinal obstruction related to pancreatic head cancer was observed. He complained of discomfort of the upper abdomen with abdominal swelling. Belching reduced these symptoms. The continuous subcutaneous injection of metoclopramide facilitated belching, and relieved discomfort of the upper abdomen. Discussion: The results suggest that the continuous administration of metoclopramide is a useful option for belching insufficiency associated with cancer-related gastrointestinal obstruction. In the presence of gastrointestinal obstruction, gas retained in the stomach may be elevated/regurgitated through the peristalsis-promoting actions of metoclopramide, promoting belching.

Palliat Care Res 2015; 10(1): 524-8

Key words: belching, gastrointestinal obstruction, metoclopramide, palliative care, cancer patients 